\title{
Effects of a tropical cyclone on a pelagic ecosystem from the physical environment to top predators
}

\author{
Paul C. Fiedler ${ }^{1, *}$, Jessica V. Redfern ${ }^{1}$, Joel Van Noord ${ }^{1,2}$, Candice Hall ${ }^{1,3}$, \\ Robert L. Pitman ${ }^{1}$, Lisa T. Ballance ${ }^{1}$ \\ ${ }^{1}$ Marine Mammal \& Turtle Division, Southwest Fisheries Science Center, National Marine Fisheries Service, \\ National Oceanic and Atmospheric Administration, 8901 La Jolla Shores Drive, La Jolla, California 92037, USA \\ ${ }^{2}$ California Wetfish Producers Association, PO Box 1951, Buellton, California 93427, USA \\ ${ }^{3}$ Ocean Associates, Inc., 4007 N. Abingdon Street, Arlington, Virginia 22207, USA
}

ABSTRACT: Tropical cyclones are environmental disturbances that may have important effects on open-ocean ecosystem structure and function, but their overall impact has rarely been assessed. The Stenella Abundance Research Line Transect and Ecosystem (STARLITE) survey, in August-November 2007, investigated spatial and temporal ecosystem variability in the eastern tropical Pacific Ocean off southwestern Mexico. Oceanographic, plankton, flyingfish, seabird, and cetacean sampling was conducted along eight $170 \mathrm{~km}$ transect lines, each of which were surveyed on 2 consecutive days at $\sim 3 \mathrm{wk}$ intervals. Tropical storm Kiko passed though the study area on 15-17 October and forced changes in the physical environment and in the ecosystem, from plankton to top predators. Kiko mixed water from beneath the strong, shallow thermocline to the surface. As a result, surface temperature decreased by $0.6^{\circ} \mathrm{C}$, the thermocline and chlorophyll maximum layer shoaled by 10-20 m, stratification decreased by $27 \%$, and chlorophyll increased by $33 \%$ at the surface and $35 \%$ over the euphotic zone. These changes persisted for at least $4 \mathrm{wk}$. Zooplankton biomass increased by $59 \%$ about 3 wk after the phytoplankton increase. Changes in the stomach fullness and diet composition of planktivorous flyingfish were consistent with the increase in zooplankton biomass. Among top predators, the sighting rate of dolphins declined, while the response of seabirds varied by species and was confounded by seasonal migration patterns. Tropical cyclones are a recurrent disturbance in this region. They initiate a bottom-up forcing of the ecosystem, creating persistent patches of higher primary and secondary production, and may be regarded as a disturbance regime.

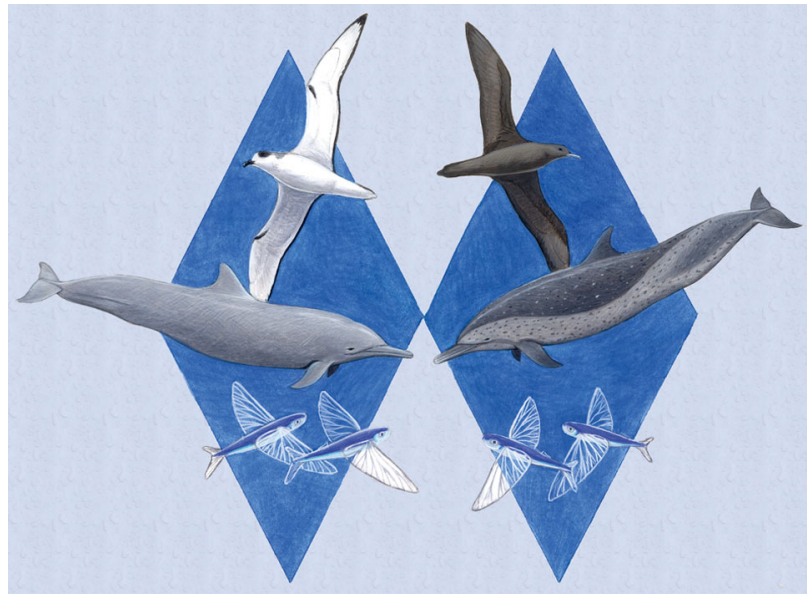

Seabirds, dolphins, and flyingfish were impacted by tropical storm Kiko through bottom-up forcing.

Painting: Sophie Webb

KEY WORDS: Pelagic ecosystem $\cdot$ Eastern tropical Pacific $\cdot$ Top predator $\cdot$ Storm $\cdot$ Disturbance $\cdot$ Bottomup forcing Resale or republication not permitted without
written consent of the publisher

\section{INTRODUCTION}

Understanding how the structure and function of marine communities and ecosystems are controlled has become an increasing concern as ecosystem changes become apparent. Effects of climate change and overfishing are being observed in long-term 
data sets (Baum \& Worm 2009, Overland et al. 2010) and can be predicted by increasingly sophisticated physical-biological ecosystem models (Barange et al. 2011). Processes that regulate the structural and functional characteristics of ecosystems-including stability, diversity, and productivity-are often classified as bottom-up (resource-driven, forced by physical factors) or top-down (consumer-driven, forced by biotic factors) (Hunter \& Price 1992, Cury et al. 2003). The relative importance of these mechanisms varies with location and scale, in both time and space (Frank et al. 2007, Fauchald et al. 2011). A third classification of wasp-waist control has been identified to explain upwelling systems dominated by effects of mid-trophic level fish stocks on both their predators and prey (Cury et al. 2003). These concepts are meaningful only within the trophic-dynamic paradigm of ecosystems organized as food chains or hierarchical webs (Lindeman 1942), which is the basis for modeling ecosystem responses to climate change and anthropogenic impacts in current 'integrated ecosystem assessment' efforts (Levin et al. 2009).

Bottom-up forcing may occur as an ecological disturbance, generally a destructive event or an environmental fluctuation. Ecological disturbance has been defined as 'any relatively discrete event in time that disrupts ecosystem, community or population structure and changes resource availability or the physical environment' (White \& Pickett 1985, p. 7). Disturbances are fundamental to theories of ecosystem state and variability, including succession (Hutchinson 1941), shifting mosaic steady state (Paine \& Levin 1981), alternative stable states (Beisner et al. 2003), and panarchy (Holling 2001). These theories are based on observations of terrestrial systems, or of simple aquatic communities (e.g. Hutchinson 1941 reviews experiments with communities of protozoa). Climate change is causing changes in disturbance patterns or regimes, such as the frequency of forest fires (Turner 2010), and may alter the frequency or intensity of tropical cyclones (Knutson et al. 2010). In the open ocean, community and ecosystem responses to stochastic disturbances such as storms are difficult to observe. Remote sensing can provide time series of disturbance effects, but only for a limited number of surface variables (e.g. temperature, chlorophyll concentration, sea surface height).

An opportunity to observe environmental disturbance and monitor its effects arose on a cruise designed to study variability in oceanic cetaceans, seabirds and their habitat (the Stenella Abundance Research Line Transect and Ecosystem cruise [STARLITE], August-November 2007). As a context for the
STARLITE observations, we present Stommel diagrams of the spatial and temporal variability in sea surface temperature and thermocline depth observed during STARLITE and the variability over a larger range of spatial and temporal scales in the eastern tropical Pacific (ETP). Stommel diagrams are often used to illustrate the relative importance of variability, and the processes that cause variability, at different spatial and temporal scales (Vance \& Doel 2010). We then describe the temporal variability in environmental and ecosystem variables measured during the 3 mo of STARLITE sampling, demonstrate the physical forcing of this variability by both mesoscale eddies and tropical cyclones, and discuss how tropical storm Kiko induced changes in the ecosystem by bottom-up forcing.

\section{MATERIALS AND METHODS}

\section{Data collection}

The STARLITE cruise was conducted aboard the NOAA ship 'McArthur II' from 18 August to 29 November 2007 approximately 200 nautical miles southwest of Manzanillo, Mexico (Fig. 1). One objective was to investigate the fine-scale spatial and temporal variability of the environment and the effects of this variability on cetacean distribution in the greater ETP. Data on cetacean distribution, school size, and school composition were collected to determine cetacean density. Oceanographic data were collected to characterize habitat and its variation over space and time. The survey design was intentionally very different than for a cetacean abundance survey: the study area was selected to cover a small region of high abundance of spotted and spinner dolphins where oceanographic spatial variability is relatively low. Eight $170 \mathrm{~km}$ sampling transects were laid out in 2 diamonds. Each of these transects was sampled in one full day and was repeated on subsequent days during each of 4 legs at approximately 3 wk intervals (Fig. 1). Logistics and weather caused some variation in timing and order of the sampling of transects.

Sampling along each of the eight $170 \mathrm{~km}$ transects began and ended with CTD stations at approximately sunrise and sunset. Underway cetacean sighting effort was conducted at 10 knots between the morning and evening CTD stations. Cetacean survey operations were conducted on the flying bridge during daylight hours (approximately 06:00 to 18:00 h) by 6 mammal observers. Each observer worked in $2 \mathrm{~h}$ rotations, staffing each of the following 3 stations on the flying 
Fig. 1. STARLITE 2007 CTD and XBT stations along repeated sampling transects off southwestern Mexico. Each of the 8 transects forming the 2 diamonds is nominally $170 \mathrm{~km}$ long and was sampled as described in 'Materials and methods'. Dotted lines are the Exclusive Economic Zones of Mexico (top right) and France (Clipperton Island, bottom left). Inset map shows location of the transects; dashed line is the NMFS/SWFSC eastern tropical Pacific survey area (Gerrodette $\&$ Forcada 2005)

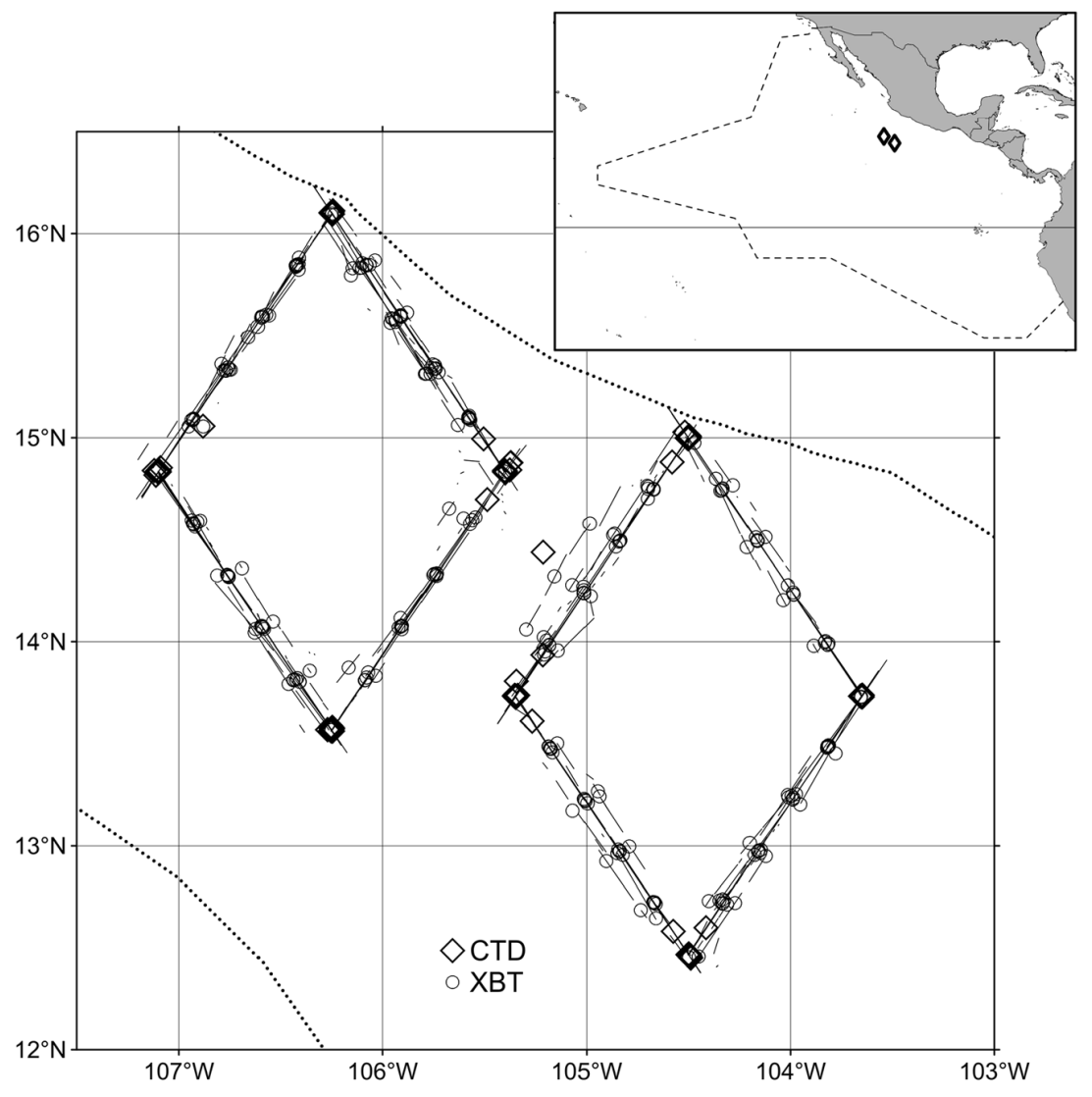

5-30 min of the XBT drops. CTD stations consisted of a Sea-Bird 911 plus CTD profile to $1000 \mathrm{~m}$ and Niskin bottle samples at 12 standard depths $(0,20,40,60$, $80,100,120,140,170,200,500$, and $1000 \mathrm{~m})$. Samples for chlorophyll were collected from bottles at all depths $\leq 250 \mathrm{~m}$. The $265 \mathrm{ml}$ chlorophyll samples from both the bucket and the CTD bottles were filtered onto GF/F filters, placed in $10 \mathrm{ml}$ of $90 \%$ acetone, refrigerated for $24 \mathrm{~h}$, and then analyzed on a Turner Designs model 10AU field fluorometer.

Dipnetting for flyingfish and other surface fauna was conducted during the evening CTD station. This station began $1 \mathrm{~h}$ after sunset and lasted for $1 \mathrm{~h}$. One or more deck lights were used to illuminate the water surface in the area of dipnet sampling. All flyingfish, squid, and myctophids caught were frozen whole. A total of 364 flyingfish individuals, of approximately 760 collected and representing a range of size classes and 8 different species, were available for stomach content analysis. Gut cavities were removed from these fish at sea and preserved in $3 \%$ formalin to be returned for laboratory analysis. Fish guts, including contents, were weighed to the nearest $1.0 \mathrm{mg}$. Prey was identified to the lowest possible taxa, counted, and weighed. The gut fullness index is a percentage surface chlorophyll analysis were collected within 
calculated using the weight of the gut contents and the weight of the entire fish, excluding the gut lining (Van Noord et al. in press).

Immediately following the evening CTD station, an oblique Bongo tow was conducted to a depth of $200 \mathrm{~m}$. The Bongo had $505 \mu \mathrm{m}$ mesh on the starboard side and $333 \mu \mathrm{m}$ mesh on the port side. The samples were preserved in formalin or frozen, labeled, and returned to our laboratory for post-cruise analysis. Small plankton volume of the $333 \mu \mathrm{m}$ samples, equal to the displacement volume of the sample after manual removal of organisms larger than $\sim 5 \mathrm{ml}$, was estimated by standard methods (Kramer et al. 1972).

Tropical cyclone data were obtained from the NOAA/National Climatic Data Center site ncdc. noaa.gov/oa/ibtracs/. Satellite composite images were obtained from NOAA/NMFS/ERDDAP (coastwatch. pfeg.noaa.gov/erddap/) for sea surface temperature (SST) (Aqua MODIS, NPP, Global, Daytime [11 $\mu \mathrm{m}$ ], Science Quality) and chlorophyll a (Orbview-2 SeaWiFS). Historical data collected from 1950 to 2008 throughout the ETP (Fig. 1 inset) were used to assess broad spatial and temporal variability. Data for 103783 stations were obtained from the NOAA/NODC World Ocean Database 2009 (nodc.noaa.gov/OC5/ WOD/pr_wod.html).

\section{Data analysis}

Mean and standard deviation of surface temperature and salinity were calculated from TSG data for intervals centered on the 6 daily CTD or XBT stations. Data collected between the daily underway XBT stations were separated into $\sim 34 \mathrm{~km}$ sampling units at the midpoint of the trackline between stations. The first and last daily intervals were about half that distance, the first beginning at the morning CTD station and the last ending at the evening CTD station. Thermocline variables were quantified as recommended in Fiedler (2010) from temperature profiles obtained by CTDs and XBTs: mixed layer depth is the depth at which temperature is surface temperature minus $0.8^{\circ} \mathrm{C}$, thermocline depth is the depth of a variable representative isotherm equal to $\sim 23^{\circ} \mathrm{C}$ in the STARLITE study area, and thermocline strength (stratification) is the standard deviation of temperature between 0 and $200 \mathrm{~m}$.

One objective of STARLITE was the comparison of 2 line-transect survey methods, closing mode and passing mode, on replicate transects. In closing mode, but not passing mode, the ship approaches or slows down to investigate a sighting for identification and group size estimation. The number of cetacean sightings identified to species was lower on days when the survey was conducted in passing versus closing mode (Schwarz et al. 2010). Consequently, the following cetacean identification categories were combined into a single 'delphinid' category (in order of total number of sightings: offshore spotted dolphin Stenella attenuata, unidentified small delphinid, eastern spinner dolphin $S$. longirostris orientalis, striped dolphin $S$. coeruleoalba, unidentified dolphin, rough-toothed dolphin Steno bredanensis, bottlenose dolphin Tursiops truncatus, unidentified medium delphinid, Risso's dolphin Grampus griseus, spinner dolphin Stenella longirostris, pygmy killer whale Feresa attenuata, short-beaked common dolphin Delphinus delphis). For analysis of individual cetacean categories (species or stocks), time series of encounter rates consist of values calculated for consecutive days sampling the same daily transect (passing mode followed by closing mode on the following day).

Time series of habitat and ecosystem variables were smoothed in plots with a loess smoother (local regression using weighted linear least squares and a 2nd degree polynomial model, using MATLAB software), with a span of 0.15. Changes in time were assessed by the Wilcoxon rank sum test of differences in medians.

Stommel diagrams were constructed for surface temperature and thermocline depth from CTD and XBT casts during STARLITE 2007 and on historical CTD, XBT and mechanical bathythermograph (MBT) casts in the ETP during 1950-2008. This larger ETP area (Fig. 1) corresponds to the NOAA/NMFS/Southwest Fisheries Science Center/Marine Mammal \& Turtle Division study area (Gerrodette \& Forcada 2005). Variability at discrete spatial and temporal scales was calculated as the standard deviation of differences of observations (RMS difference) separated in space $(\mathrm{km})$ and time (days) by $\leq 1$ to $10^{5}$ (logscaled bins of $0,0.1,0.2 \ldots 5)$. The space and time axes of these plots were scaled by a factor of 2, because differences over a separation of $x$ represent variability with a period of $2 x$.

\section{RESULTS}

The relatively low variability of oceanographic variables in the STARLITE study area is confirmed in the Stommel diagrams of surface temperature and thermocline depth for the 397 stations in the STARLITE 2007 data set and for historical stations in the ETP during 1950-2008 (Fig. 2). For both variables, 


\section{Surface temperature}

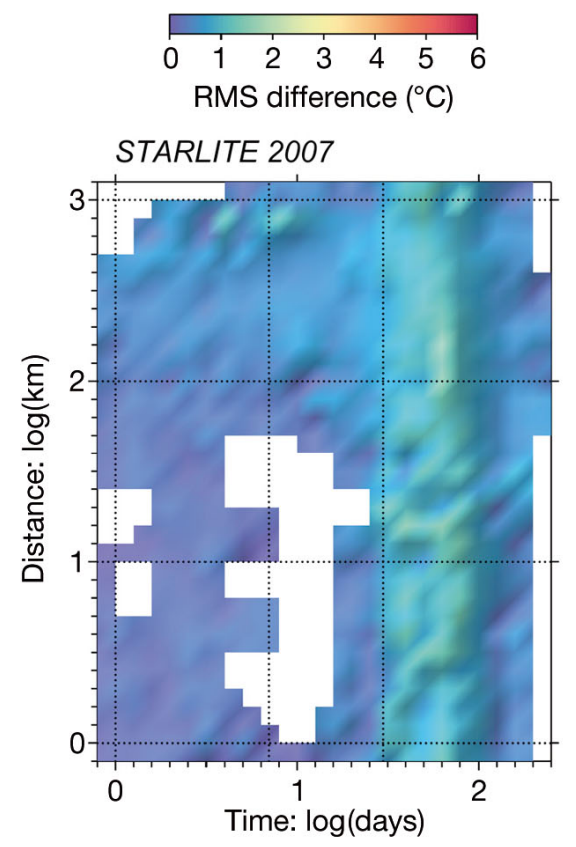

\section{Thermocline depth}

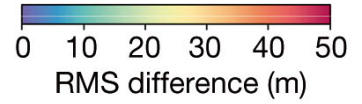

STARLITE 2007

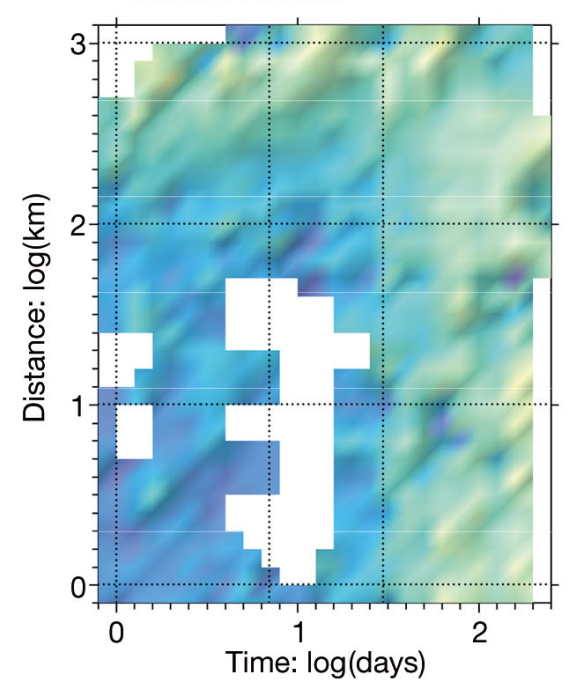

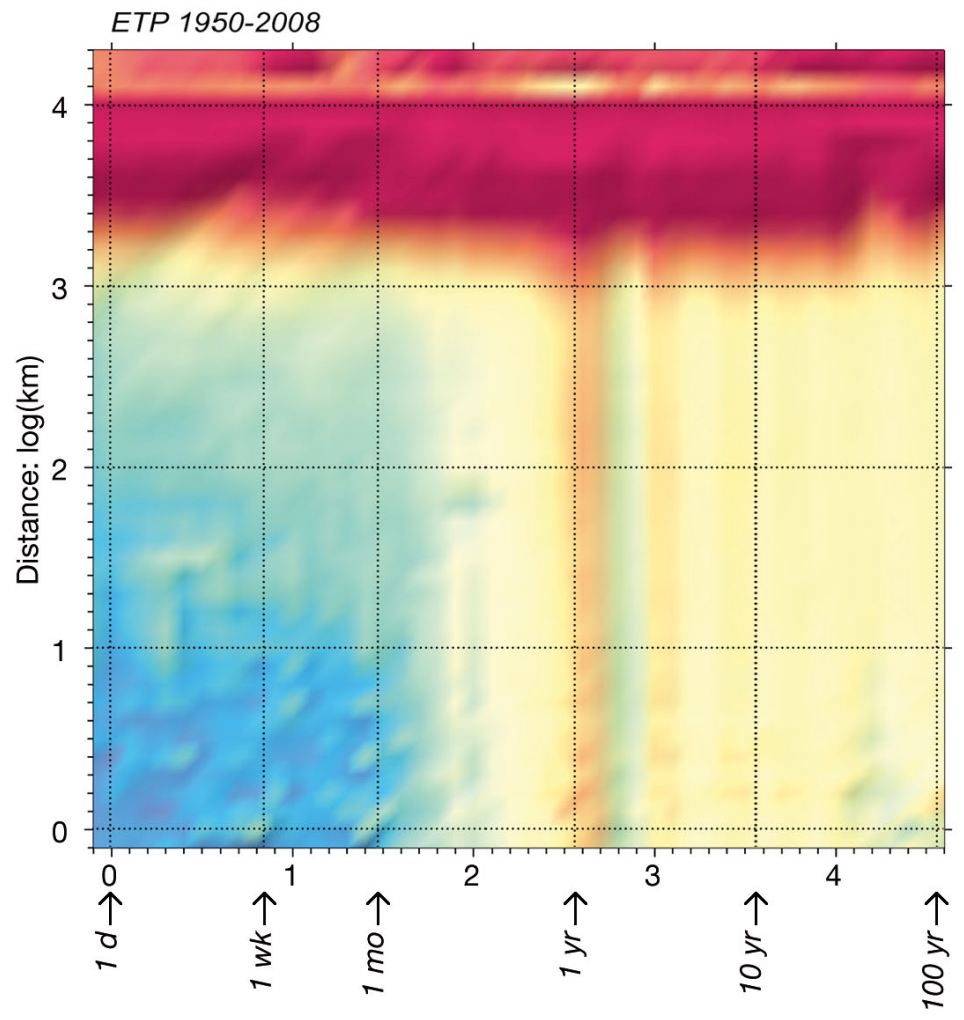



Fig. 2. Stommel diagrams (RMS difference) of surface temperature and thermocline depth during STARLITE 2007 (left) and 1950-2008 in the eastern tropical Pacific (ETP; right). Number of pairs of observations increases with increasing scales of separation from $\sim 5$ to 1000 for STARLITE and from $\sim 50$ to $10^{9}$ for the ETP 
variability in the STARLITE data set is lower than in the ETP as a whole, within the range of temporal and spatial scales of the STARLITE data set. The exception is surface temperature at scales $>1$ mo $(\log [30$ days] $=1.48$ ), reflecting changes caused by tropical storm Kiko, which crossed the STARLITE study area during the first week of Leg 3 (Fig. 3). All sampling operations were interrupted for at least one day due to high winds and sea state.

Time series of observed oceanographic variables are illustrated in Fig. 4. Beaufort sea state is an index of local wind speed and affects viewing conditions for mammal and seabird observers. Several oceanic or atmospheric weather events can be discerned. High Beaufort sea states during the first week of Leg 1 were caused by winds associated with the passage of tropical storm Henriette along the coast of Mexico to the north of the study area (Fig. 3). Sea surface temperature cooled by $\sim 1^{\circ} \mathrm{C}$ and variability (standard deviation of surface temperature, sdT) decreased at this time, but there were no significant subsurface changes. In contrast, transient changes in surface temperature, mixed layer and thermocline depths, and stratification occurred once during Leg 2 and once during Leg 4 . Isotherm displacements observed at STARLITE stations (Fig. 5) show the signatures of mesoscale eddies that passed through or near the study area. A cyclonic eddy shoaled isotherms in the fourth week of September and an anticyclonic eddy deepened isotherms in the second week of November (these eddies are named Candice and Annette, respectively, in the time series plots).

Kiko caused surface mixing, which lowered surface temperature mean (by $>2^{\circ} \mathrm{C}$ ) and variability, increased chlorophyll, shoaled the mixed layer and thermocline, and decreased stratification as the storm passed through the study area and then strengthened while moving along the coast to the north of the

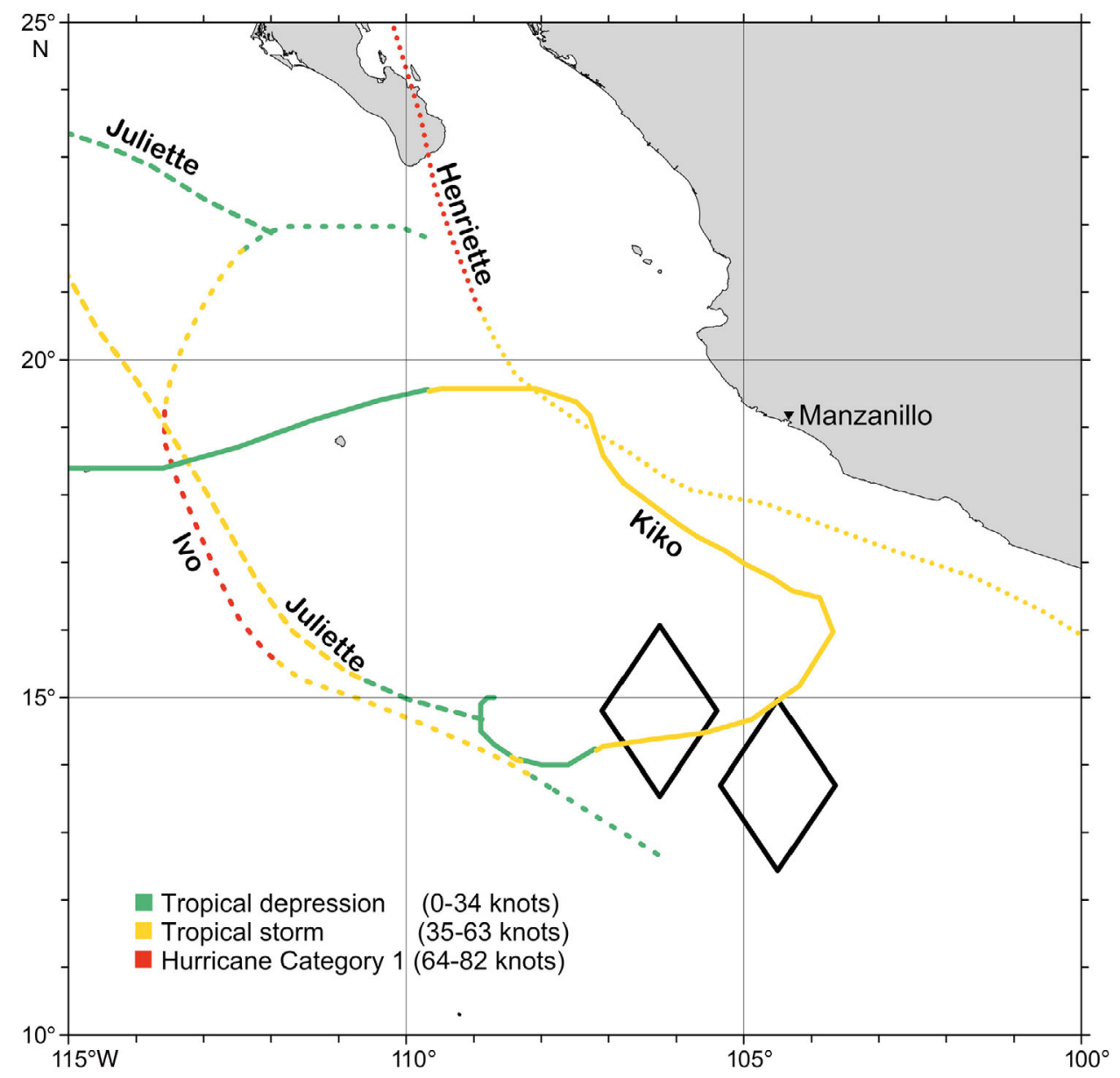

Fig. 3. Tracks of cyclones off Mexico during STARLITE 2007 (18 August-19 November, black diamonds) with dates and maximum sustained wind speed: Henriette (31 August-5 September, 75 knots), Ivo (18-25 September, 70 knots), Juliette (29 September-4 October, 50 knots) and Kiko (15-24 October, 60 knots). From www.ncdc.noaa.gov/oa/ibtracs/. All cyclones moved northward 

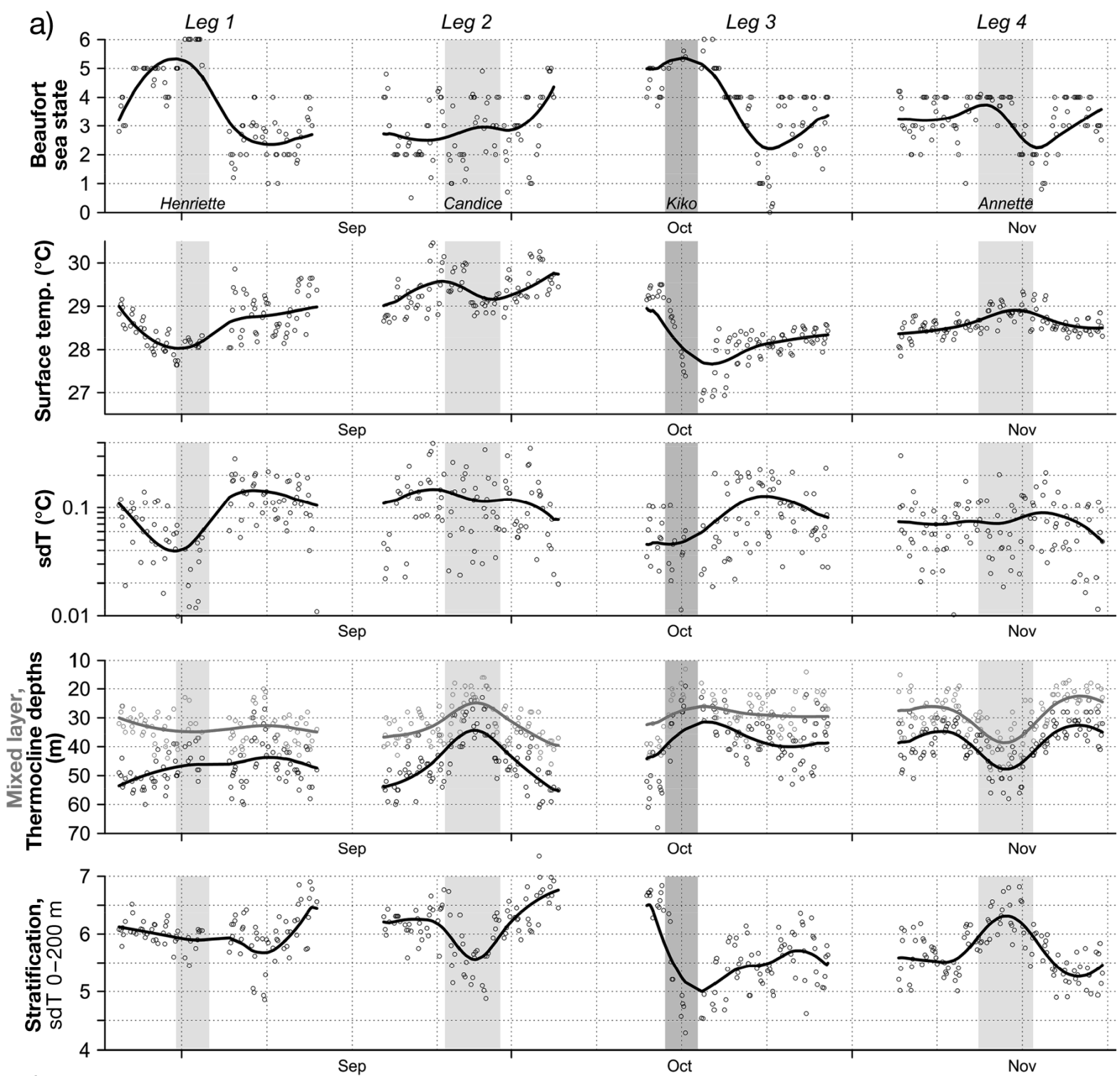

b)
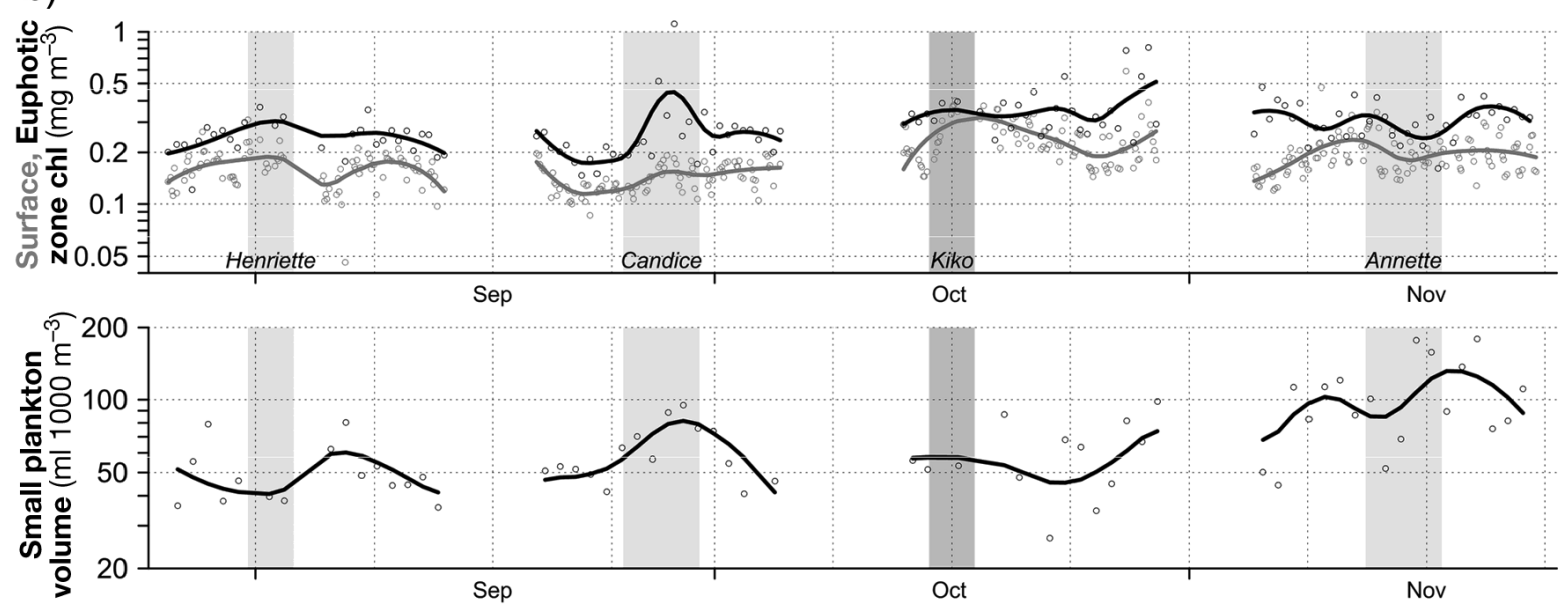

Fig. 4. Time series of (a) physical environmental variables in the STARLITE data set: Beaufort sea state, surface temperature, standard deviation of surface temperature (sdT), mixed layer and thermocline depths, and stratification (sdT; 0-300 m); and (b) biological variables in the STARLITE data set: surface and mean euphotic zone chlorophyll, and small plankton volume. Lines are LOESS smooths of the point observations. Dark gray bar: 15-17 October, when Kiko passed through the study area. Light gray bars: times when tropical storm Henriette and eddies Candice and Annette impacted the study area (see 'Results') 


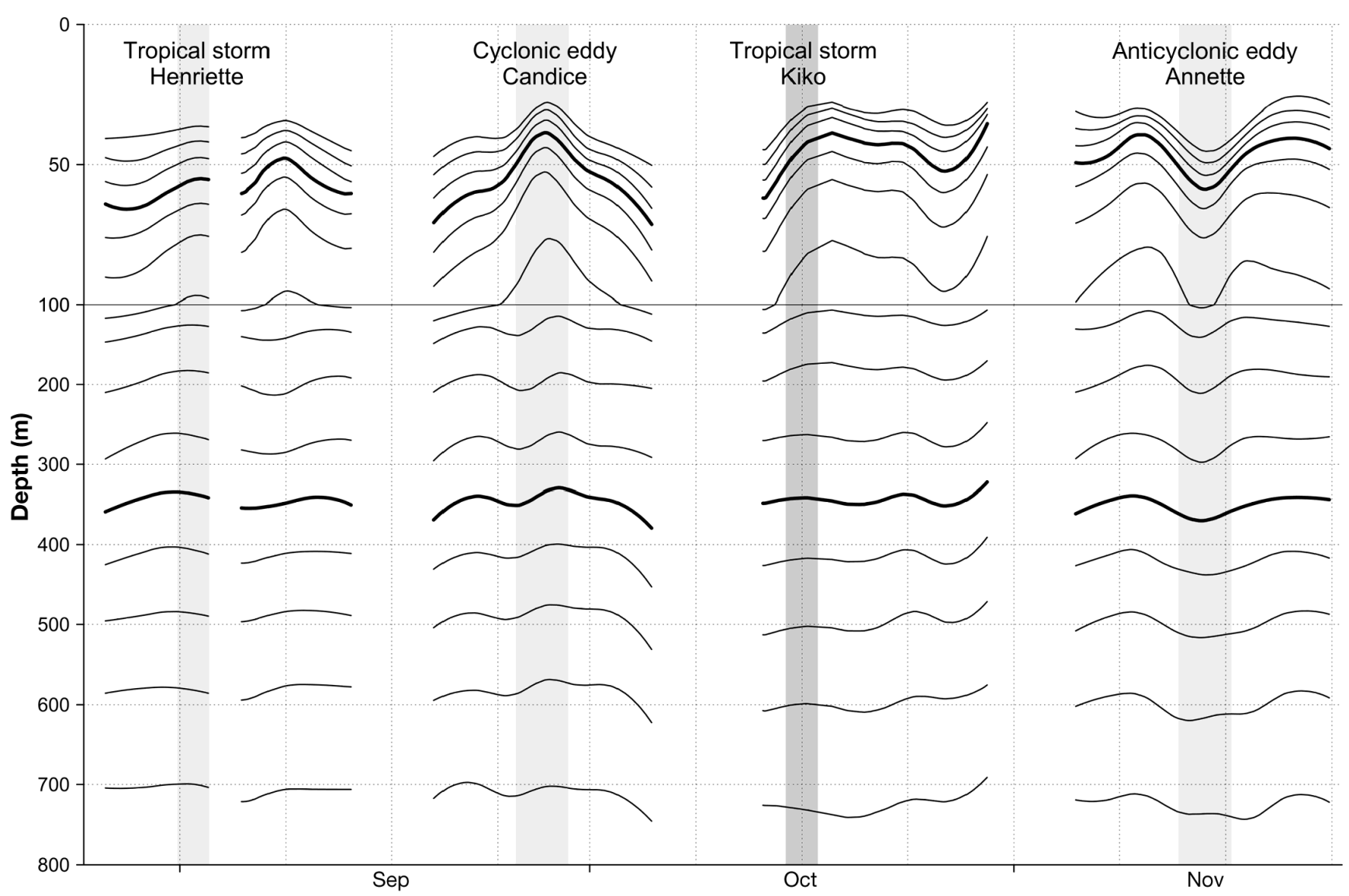

Fig. 5. Time series of isotherm depths at STARLITE CTD and XBT stations. The vertical axis is expanded for the surface layer $(0-100 \mathrm{~m})$. In the surface layer, isotherms are 26 to $14^{\circ} \mathrm{C}$ at $2^{\circ} \mathrm{C}$ intervals. In the deeper layer, isotherms are 14 to $6^{\circ} \mathrm{C}$ at $1{ }^{\circ} \mathrm{C}$ intervals. The 20 and $10^{\circ} \mathrm{C}$ isotherms are in bold. Gray bars as in Fig. 4

study area (Fig. 4a). Conditions returned towards pre-Kiko values during the remainder of the leg. However, pre- and post-Kiko means were different (Table 1): lower and less variable surface temperature, more shallow mixed layer and thermocline, and lower stratification. The change in vertical temperature structure (Fig. 6a) reflects the mixing and upwelling of cold, subthermocline water into the warm mixed layer, as has been observed (Shi \& Wang 2011, Sun et al. 2012) and modeled (Liu et al. 2009) for other tropical cyclones.

Changes in biological variables were also observed, both concurrent with and subsequent to Kiko (Fig. 4b). Surface chlorophyll increased immediately and approached the mean euphotic zone value, due to the mixing of phytoplankton from the deep chlorophyll maximum. Mean euphotic zone chlorophyll also increased, but with a lag of several days toward the end of Leg 3, suggesting a growth response to the mixing of deeper, nutrient-rich water into the surface layer. However, physical processes such as local convergence of surface waters after the initial upwelling/ divergence may have contributed to this change (Sun et al. 2012). Chlorophyll levels declined between Legs 3 and 4, but remained higher than before Kiko until the end of the cruise (Table 1). Vertical profiles of chlorophyll (Fig. 6b) show a subsurface chlorophyll maximum that was $\sim 0.2 \mathrm{mg} \mathrm{m}^{-3}$ at $40-60 \mathrm{~m}$ depth before Kiko, shoaled to $20 \mathrm{~m}$ during Kiko, increased to $\sim 1 \mathrm{mg} \mathrm{m}^{-3}$ two weeks later, and subsequently decreased to $\sim 0.3 \mathrm{mg} \mathrm{m}^{-3}$ at $40 \mathrm{~m}$ depth $1 \mathrm{mo}$ after Kiko. These changes reflect both physical processes and biological responses. An ensuing biological response was observed that has not been previously documented: small plankton volume increased at the end of Leg 3 and during Leg 4 it was about twice the pre-Kiko level.

Satellite imagery gives a broader view of the surface changes induced by Kiko (Fig. 7). The passage of the storm resulted in local surface cooling and chlorophyll enrichment that persisted for several weeks. As Kiko was approaching, surface waters between the study area and the coast were warm, with moderate chlorophyll levels (12 October). As 
Kiko passed through the study area and veered to the northwest along the coast, surface cooling and chlorophyll enrichment can be seen along the track of the storm (20 October). The magnitude of these effects varied, but note the patch of cold, highchlorophyll water just after the turn of the storm track to north of the study area. During the composite periods following Kiko (28 October and 5 November), local patches of cold and high-chlorophyll water persisted along the storm track. At these times, the cold

Table 1. Medians for different variables measured off Mexico before (26 Aug-5 Oct) and after (20 Oct-23 Nov) tropical storm Kiko passed through. Diff.: 1, 2 or 3 symbols indicate whether medians were significantly different before and after Kiko (Wilcoxon rank sum test: $\mathrm{p}<0.01,<0.001$, or $<$ 0.0001 , respectively), and whether the median increased $(>)$ or decreased $(<)$. sd $=$ standard deviation; $\mathrm{ns}=$ not significant $(p>0.01)$

\begin{tabular}{|c|c|c|c|}
\hline & Before & Diff. & After \\
\hline \multicolumn{4}{|l|}{ Oceanographic variables } \\
\hline Beaufort sea state & 3 & ns & 3.5 \\
\hline Surface temperature & 29.02 & $\gg>$ & 28.46 \\
\hline sd (Surface temperature) & 0.097 & $\gg>$ & 0.0708 \\
\hline Surface salinity & 33.70 & $>$ & 33.60 \\
\hline sd (Surface salinity) & 0.051 & $>$ & 0.0390 \\
\hline Mixed layer depth & 33 & $>>$ & 29 \\
\hline Thermocline depth & 48 & $>>$ & 38 \\
\hline Stratification & 6.07 & $\gg>$ & 5.65 \\
\hline \multicolumn{4}{|l|}{ Biological variables } \\
\hline Surface chlorophyll & 0.150 & $\ll<$ & 0.200 \\
\hline Euphotic zone chlorophyll & 0.236 & $\ll<$ & 0.320 \\
\hline Small plankton volume & 51.2 & $<$ & 81.6 \\
\hline \multicolumn{4}{|l|}{ Seabird sightings per day } \\
\hline Juan Fernandez petrel & 134.8 & $\gg>$ & 2.1 \\
\hline Wedge-tailed shearwater & 49.3 & $\gg>$ & 4.7 \\
\hline Leach's storm petrel & 15.1 & $<$ & 38.5 \\
\hline Sooty tern & 0 & $<<<$ & 2.7 \\
\hline Red-footed booby & 21.8 & ns & 23.3 \\
\hline Brown booby & 7.7 & ns & 11.1 \\
\hline \multicolumn{4}{|l|}{ Seabird feeding flocks, daily } \\
\hline Density (flocks $1000 \mathrm{~km}^{-2}$ ) & 1.61 & $\gg>$ & 0.54 \\
\hline Diversity (species flock ${ }^{-1}$ ) & 3.0 & ns & 4.3 \\
\hline Size (birds flock ${ }^{-1}$ ) & 28.8 & ns & 22.3 \\
\hline Size (boobies flock ${ }^{-1}$ ) & 0.8 & $<$ & 2.1 \\
\hline \multicolumn{4}{|c|}{ Cetacean encounter rates (schools per $100 \mathrm{~km}$ ) } \\
\hline Delphinids & 8.7 & $>$ & 4.1 \\
\hline Offshore spotted dolphins & 3.8 & ns & 1.9 \\
\hline Eastern spinner dolphins & 1.0 & ns & 0.8 \\
\hline Striped dolphins & 0 & ns & 0 \\
\hline \multicolumn{4}{|l|}{ Flyingfish fullness index } \\
\hline Exocoetus monocirrhus & 0.42 & $\ll<$ & 0.76 \\
\hline Cheilopogon xenopterus & 0.28 & $<$ & 0.65 \\
\hline \multicolumn{4}{|c|}{ Flyingfish diet composition (\%) } \\
\hline \multicolumn{4}{|l|}{ Exocoetus monocirrhus } \\
\hline Copepods & 93 & 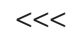 & 99 \\
\hline Amphipods & 3 & $\gg>$ & 0 \\
\hline \multicolumn{4}{|l|}{ Cheilopogon xenopterus } \\
\hline Copepods & 15 & ns & 21 \\
\hline Amphipods & 05 & $\mathrm{~ns}$ & 18 \\
\hline Gelatinous plankton & 50 & $>$ & 4 \\
\hline
\end{tabular}

and high-chlorophyll water in the lower right corner of the composites was the result of the seasonal wind jet in the Gulf of Tehuantepec that causes intense vertical mixing (Liang et al. 2009).

Kiko produced a large and persistent change in both the local physical and biological environment. Our observations show concurrent changes in top predators (Fig. 8). Sighting densities for the 6 most abundant seabird species are plotted in Fig. 8a. The 2 most abundant species, Juan Fernandez petrel Pterodroma externa and wedge-tailed shearwater Puffinus pacificus, nearly disappeared after Kiko (Fig. 8a, top, Table 1). Increases in apparent abundance were observed for Leach's storm petrel Oceanodroma leucorhoa and sooty tern Sterna fuscata (Fig. 8a, middle, Table 1). Red-footed and brown boobies (Sula sula and $S$. leucogaster, respectively) are both residents in the region; sighting rates were low during Kiko, but soon returned to pre-storm levels (Fig. 8a, bottom, Table 1). Bird sighting conditions, unlike cetacean sightings, are not affected by sea state.

Cetacean relative abundances are plotted in Fig. 8b. Encounter rates for the combined delphinid category declined during the storm (due to poor sighting conditions) and did not recover to pre-storm levels during Leg 4 (Table 1). Delphinid density (encounter rate of individuals) varied in concert with encounter rate of groups (Fig. 8b, upper), and also declined (median 584 to 373) but was not significantly different before and after Kiko (not shown). Encounter rates by taxonomic categories show high variability during each leg (Fig. 8b, lower). The 2 most abundant taxa, offshore spotted and eastern spinner dolphins, tended to covary because they often schooled together. There were no significant differences in encounter rates before and after Kiko for any individual cetacean category.

Flyingfish were the only planktivorous fishes regularly sampled. Feeding success (gut fullness) for the 2 most abundant species increased 3 wk after Kiko (Fig. 8c), when small plankton volume also increased (Fig. 4b); the increases from before to after Kiko were statistically significant (Table 1). Diet composition changes were also observed. The diet of Exocoetus monocirrhus was consistently dominated by copepods, but the proportion of copepods increased and the proportion of amphipods decreased after Kiko. The diet of Cheilopogon xenopterus showed a significant reduction in the proportion of small gelatinous plankton after Kiko. Relative abundance estimates recorded during dipnetting do not show a change in abundance of flyingfish before and after Kiko (not shown). 

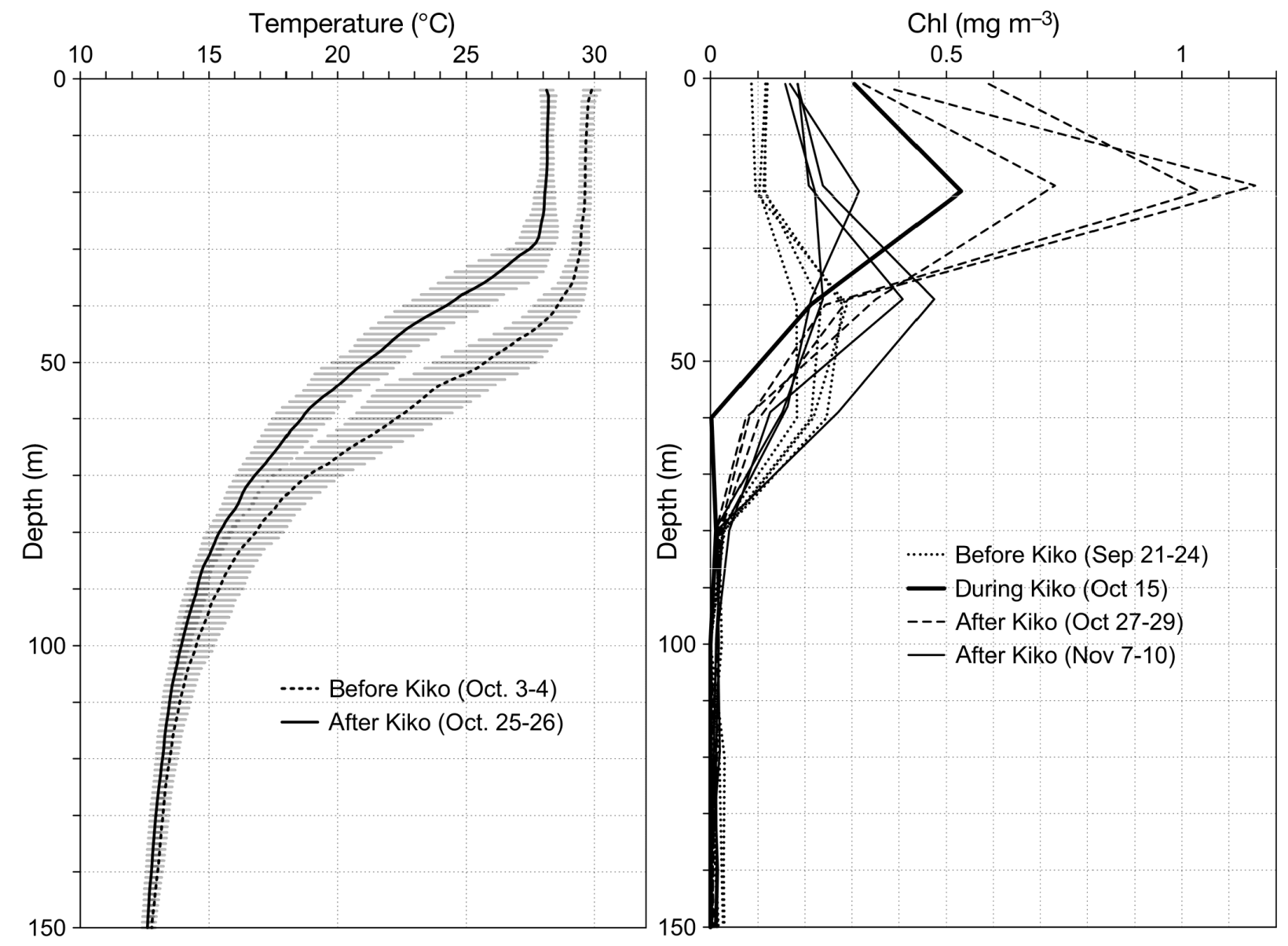

Fig. 6. (a) Temperature profiles (mean and $95 \%$ confidence limits) observed along the NE transect of the NW diamond and

(b) chlorophyll bottle sample profiles observed at the southern station of the NW diamond (Fig. 1) before and after Kiko

\section{DISCUSSION}

Temporal and spatial variability of ETP SST from Fig. 2 is plotted as a 3-dimensional Stommel diagram in Fig. 9. It shows that variability increases with scale as expected (Platt \& Denman 1975), especially at large spatial scales $(>1000 \mathrm{~km})$ spanning water masses with fundamentally different oceanographic characteristics (Fiedler \& Talley 2006). Temporal variability shows maxima at the annual and ENSO (3-7 yr) scales, which are the first 2 ridges in the temporal dimension. Variability forced by disturbances such as tropical cyclones in this region is in the relatively low corner of this surface, corresponding to mesoscales of $\sim 1-100 \mathrm{~km}$ and days, but is likely underestimated since shipboard sampling activity is curtailed by storms.

Tropical cyclones are not the only source of mesoscale variability in this region. Eddies are formed along the coast primarily by instabilities in the coastal circulation, but also by seasonal wind jets through trans-isthmus gaps to the southeast of our study area (Willett et al. 2006). These eddies are 90-250 km in diameter and move westward at 10-15 $\mathrm{km} \mathrm{d}^{-1}$. Signatures of one cyclonic and one anticyclonic eddy were observed in the STARLITE time series (Figs. 4a \& 5). Both, eddies and tropical storms caused changes in the thermal structure of the water column. Although the eddy displacements of isotherms extended much deeper than the nearsurface changes resulting from surface layer mixing by Kiko (Fig. 5), the eddies did not force a persistent change in thermal structure as did Kiko. Other than a transient increase in surface chlorophyll associated with the cyclonic eddy, there was no obvious change in phytoplankton or zooplankton associated with the passage of the eddies (Fig. $4 \mathrm{~b}$ ).

The local changes in the stratification of the water column along the storm path caused by Kiko, and the resulting cooling and chlorophyll enrichment of surface waters, have been observed in association with cyclones in other ocean regions (Wang et al. 2011). 

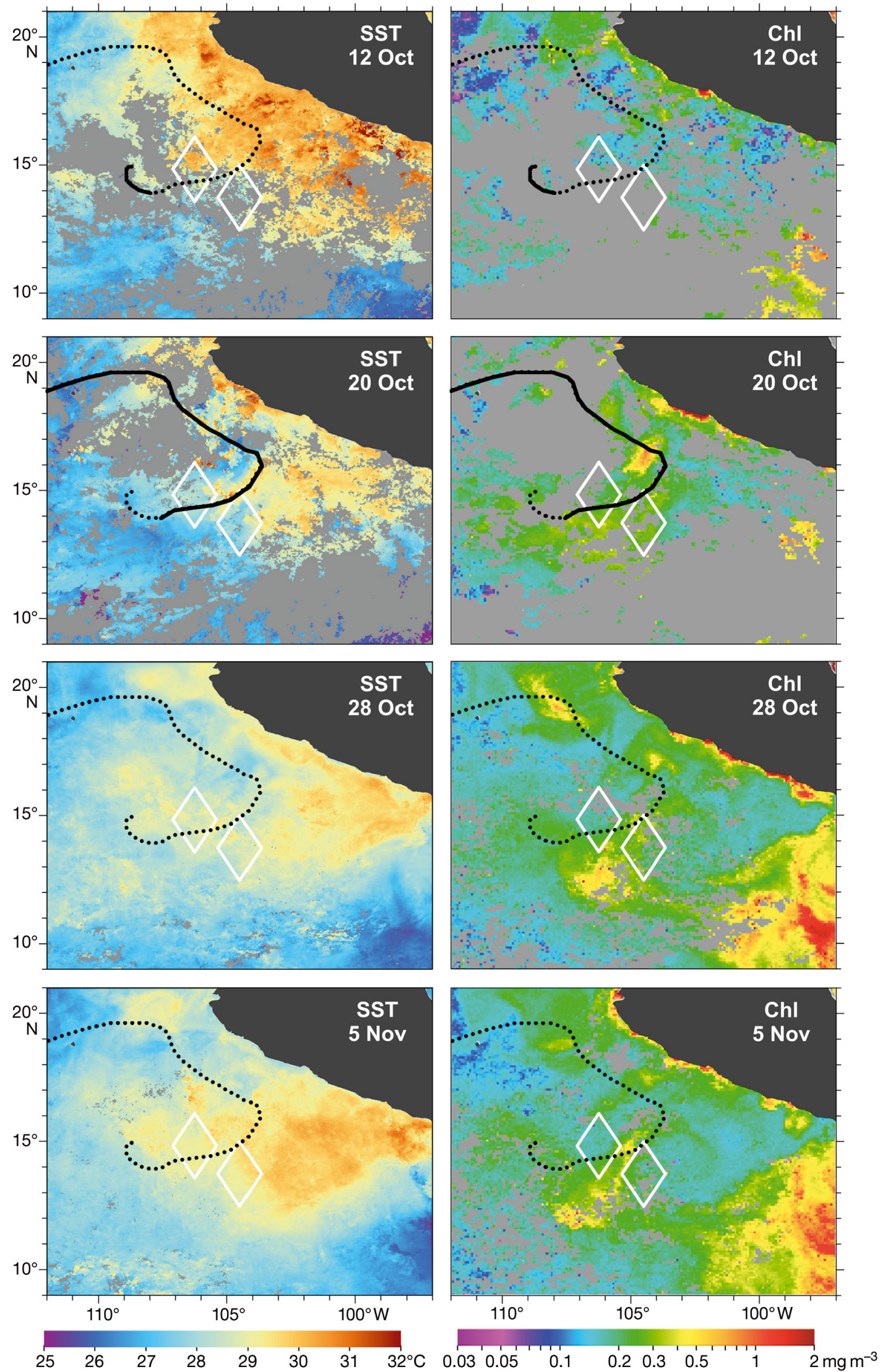

Fig. 7. Eight-day composites (nominal date is Day 4) of sea surface temperature (SST; left) and chlorophyll (right) and passage of tropical storm Kiko through the STARLITE 2007 study area (white diamonds). Dotted lines are the track of Kiko; solid lines indicate where the storm was present during the composite period. Gray pixels are missing data 
a)
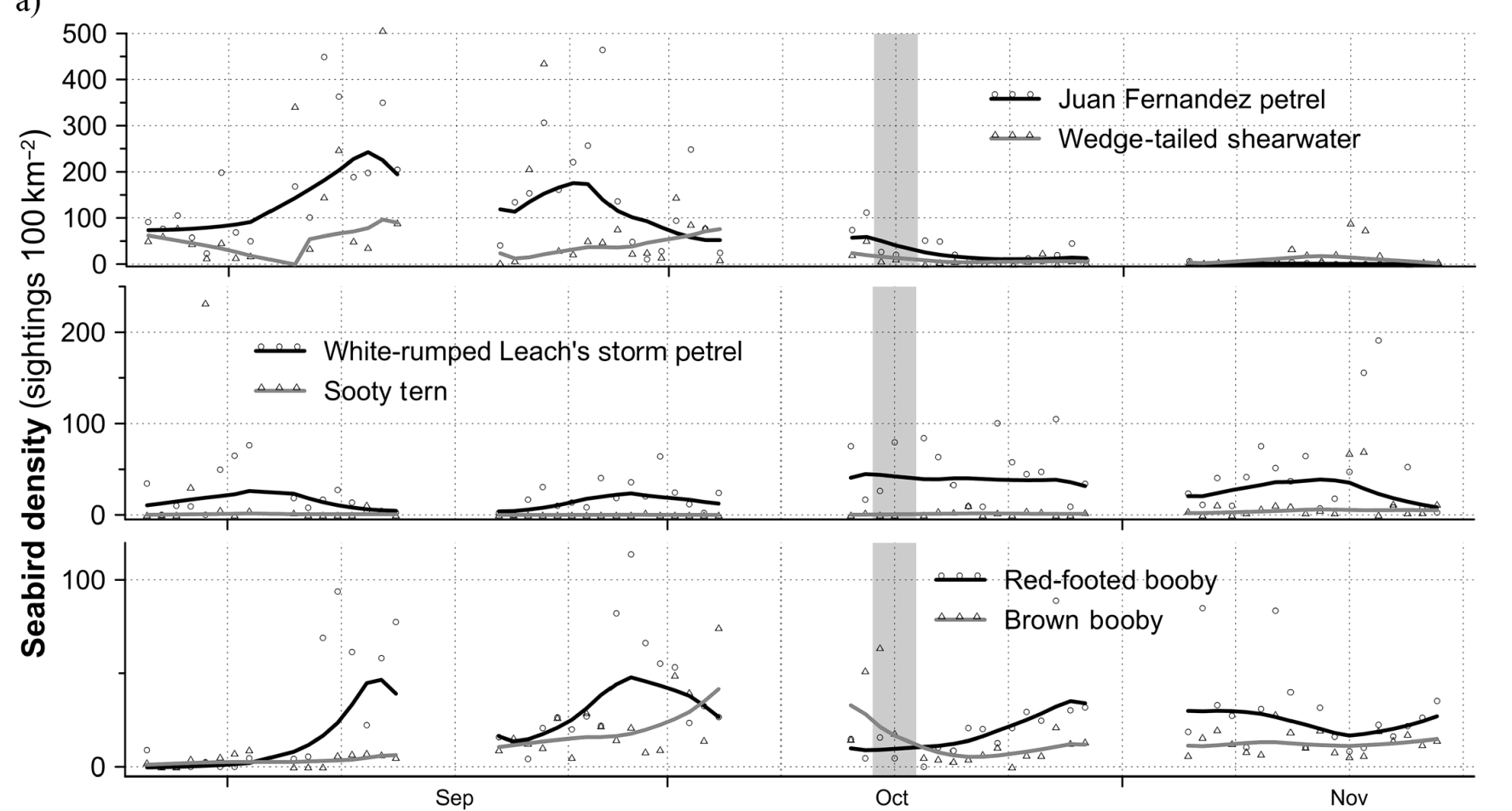

b)
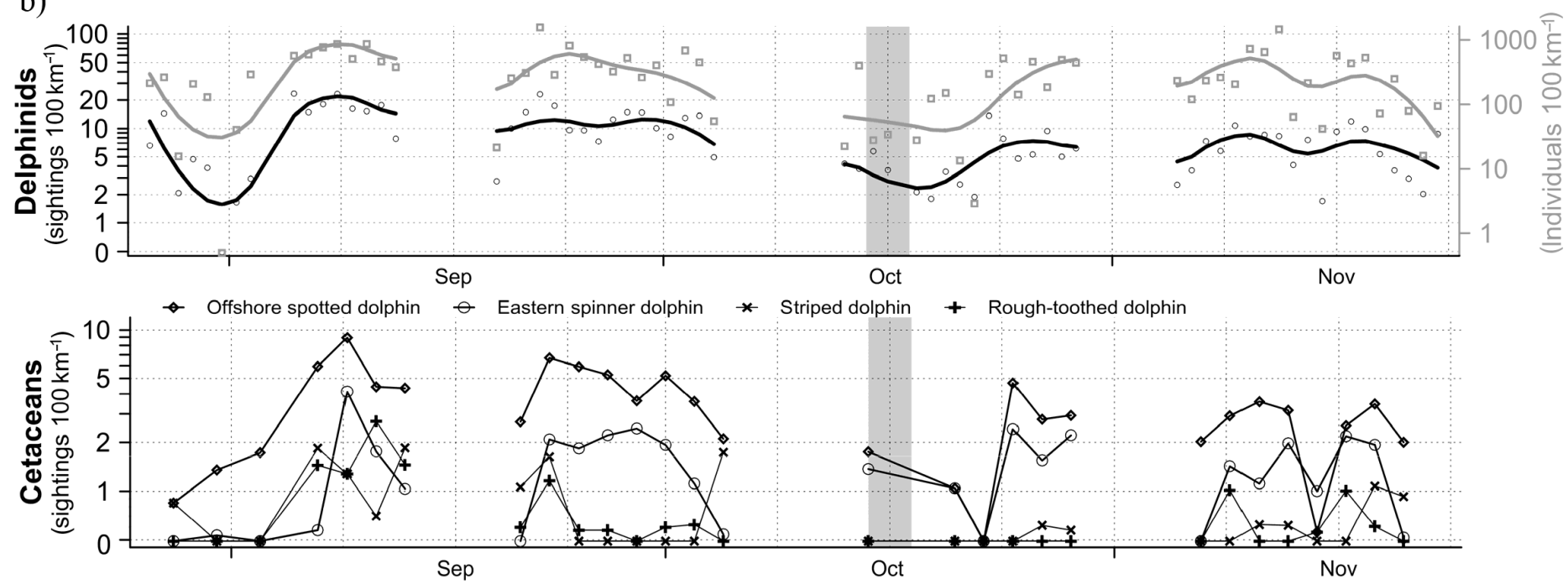

c)

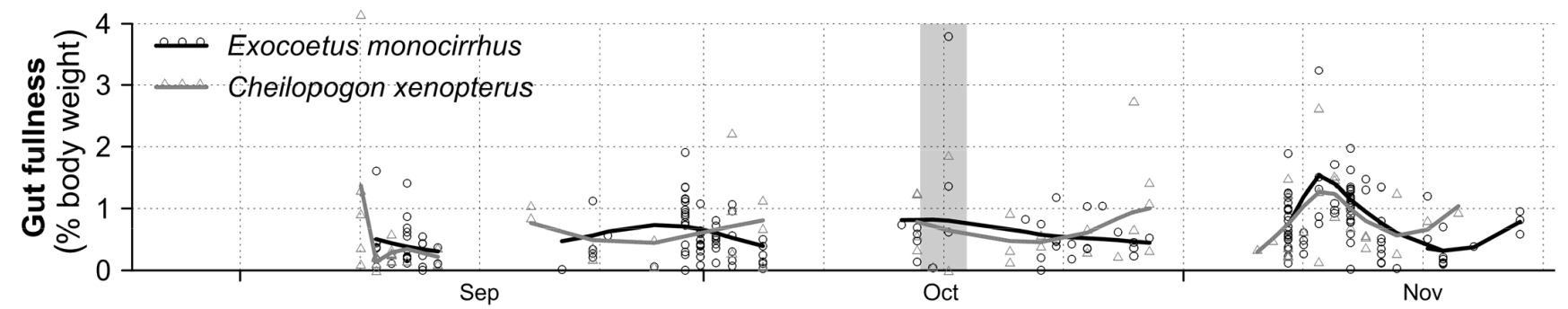

Fig. 8. Time series of (a) daily densities of the 6 most abundant seabirds in the STARLITE data set (sightings $100 \mathrm{~km}^{-2}$ ), $(\mathrm{b})$ relative abundance (encounter rates, sightings $100 \mathrm{~km}^{-1}$ and individuals $100 \mathrm{~km}^{-1}$ ) of the delphinid category of cetaceans (top, daily values) and the 4 most common cetaceans (bottom, sightings $100 \mathrm{~km}^{-1}$ ), and (c) gut fullness for the 2 most common flyingfish species. Gray bar marks 15-17 October, when tropical storm Kiko passed through the study area 
Fig. 9. Stommel diagram of the variability of sea surface temperature in the eastern tropical Pacific over a range of temporal and spatial scales. The vertical axis is standard deviation of differences (RMS difference, 0 to $10^{\circ} \mathrm{C}$ ) between observations separated by the spatial and temporal intervals indicated on the horizontal axes. Grid lines on the time axis mark one day, week, month, year, decade, and century

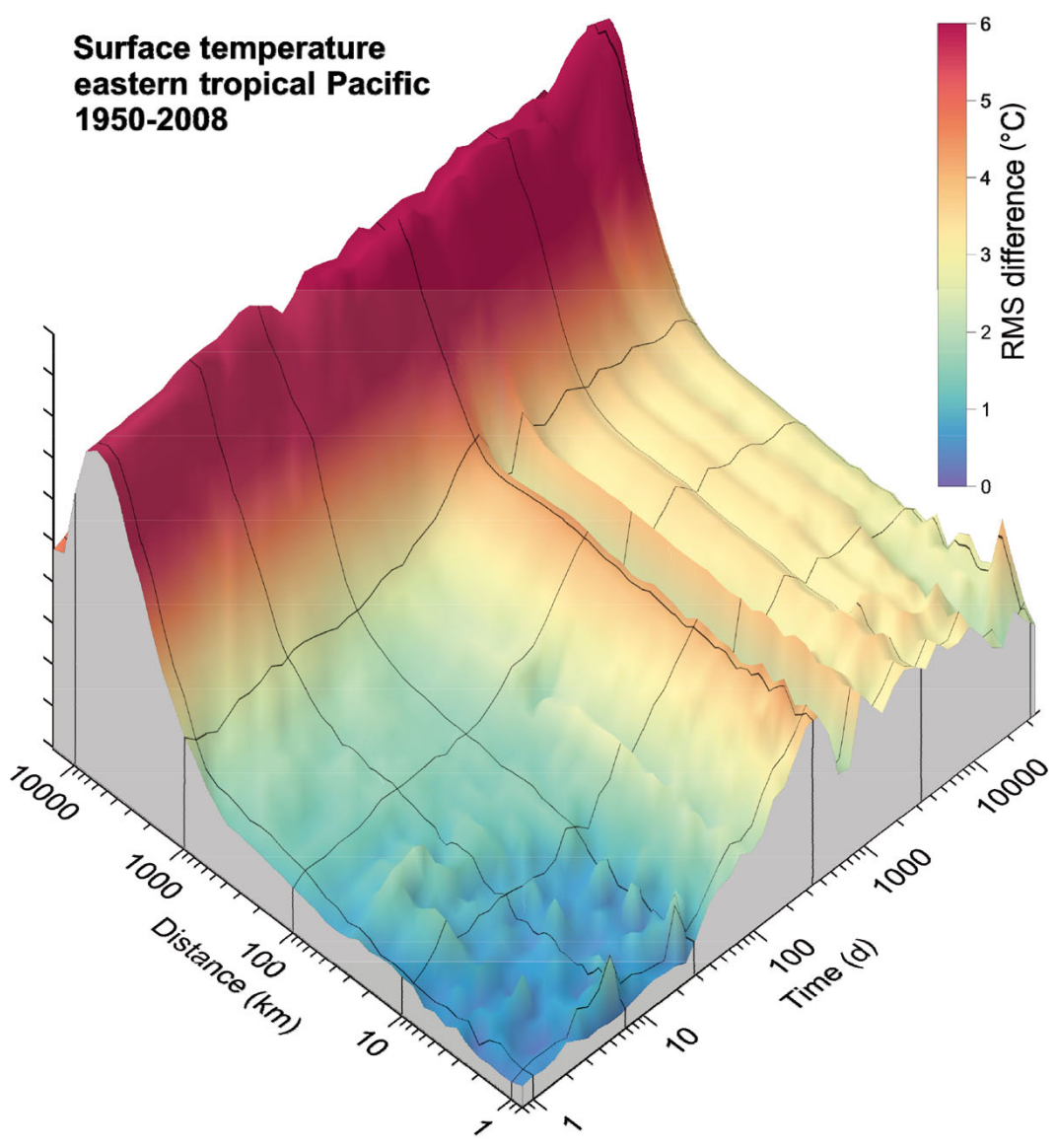

Sun et al. (2012, and references therein) summarized the ocean effects of tropical cyclones as sea surface cooling, enhanced entrainment and vertical mixing, inertial oscillation, and enhanced phytoplankton blooming. Shi \& Wang (2011) found, in satellite imagery, that SST dropped more than $1^{\circ} \mathrm{C}$ and satellite-imaged chlorophyll a was elevated along the track of Hurricane Earl along the US east coast in 2010. Liu et al. (2009) made similar observations for Hurricane Katrina in the Gulf of Mexico in 2008. Integrated studies in the western subtropical North Atlantic (Babin et al. 2004, Hanshaw et al. 2008) found that surface chlorophyll increases by 5 to $91 \%$ after the passage of tropical cyclones, the effect increasing with the strength of the storm and persisting for 2 to $3 \mathrm{wk}$. In contrast, a study in the western North Pacific subtropical ocean, where the nutricline is relatively deep, found that only 2 of 11 cyclones induced a phytoplankton bloom (Lin 2012). A similar analysis is needed to assess the net overall effect of tropical storms in the northeastern tropical Pacific, where the thermocline/nutricline is more shallow and strongly stratified.

Phytoplankton blooms induced by vertical mixing of nutrients from depth are essential to the function- ing of extra-tropical pelagic ecosystems, the 'Westerlies biome' of Longhurst (2007). For tropical cyclones, Price at al. (1994) showed that the change in vertical structure of the water column resulting from North Atlantic hurricanes was caused by a combination of wind-induced vertical mixing and vertical upwelling associated with Ekman pumping by the cyclonic winds. Therefore, the changes in thermocline depth and stratification that we observed are not analogous to deep winter mixing at higher latitudes where the seasonal thermocline is eroded and deepens (see oceanworld.tamu.edu/resources/ocng_textbook/ chapter06/chapter06_04.htm). Mixing from both tropical cyclones and westerly winter mixing inputs nutrients into the surface layer and can stimulate phytoplankton production at the 'bottom' of an ecosystem's food web.

The changes we observed during the 2-3 wk after Kiko passed through our study area are consistent with bottom-up forcing of ecosystem change. Chlorophyll increased in the euphotic zone overall, probably due to phytoplankton production in response to nutrient input by wind mixing. Small-plankton volume also increased. This could not have been a population response in the time frame of our study, 
but could represent enhanced growth and survival of individual plankters. Feeding success of planktivorous flyingfish, as evidenced by stomach fullness, increased concurrently. Presumably, this change would ultimately increase survival and reproductive success of these mid-trophic-level fish and increase forage availability to top predators such as seabirds and cetaceans. Regular, long-term monitoring surveys are needed to observe such population effects.

Most observations of hurricane effects on top predators are based on data associated with coastal or island regions. For example, cetaceans have undergone mass strandings (Marsh 1989, MignucciGiannoni et al. 2000), and island-associated populations have suffered increased predation (Fearnbach et al. 2012) and calf loss (Miller et al. 2010). Seabirds are commonly displaced or blown inland (Tuck 1968, Wiley \& Wunderle 1993 and references therein, Bugoni et al. 2007, Hass et al. 2012) and reproductive success can be dramatically decreased due to direct mortality of eggs and chicks (White et al. 1976 and references therein). In contrast, we know very little about the impact of hurricanes on cetaceans or seabirds in the open ocean, although seabirds are known to ride storm fronts (Manikowski 1971, Blomqvist \& Peterz 1984) and perhaps are capable of avoiding cyclones altogether. Such direct effects on the abundance and distribution of top predators are potentially 'top-down' in the context of ecosystem regulation.

We did observe changes in the abundance of some top predators concurrent with Kiko, but most of these changes cannot be attributed definitively to the storm or the environmental effects of the storm. Abundance of Juan Fernandez petrels and wedgetailed shearwaters decreased after Kiko, but the time period also corresponds to their departure from the ETP to their breeding colonies in the southern hemisphere. Abundance of Leach's storm petrel increased, but they typically arrive in the ETP during this time, after breeding in the north Pacific during the boreal summer. Density of seabird feeding flocks decreased, and the flocks became more dominated by resident boobies, when the 2 most abundant seabirds departed for breeding. It is possible that the increase in Leach's storm petrel could have been influenced by Kiko, in addition to seasonal movements, as it is the only planktivore of the 6 seabird species analyzed in this study.

Similarly, the 5 sightings of blue whales during the survey all occurred in November, when these whales may be migrating from summer feeding grounds off California to wintering grounds in the vicinity of the
Costa Rica Dome to the south of the study area (Reilly \& Thayer 1990, Bailey et al. 2009). The decrease in abundance of delphinids after Kiko may be at least partly due to seasonal migration, although the migration patterns of these animals are not well known except for the rare great whales. It is possible that annual patterns of storm frequency in this region have influenced the evolution of whale and seabird migration to exploit seasonal food resources in the ETP, but this question is beyond the scope of the present study.

In order to sample total ecosystem response to a tropical storm, shipboard sampling is needed. However, ship surveys cannot be scheduled for stochastic disturbances and repetitive post-disturbance monitoring is expensive. We were fortunate to have a multidisciplinary and repetitive sampling program underway when tropical storm Kiko disrupted the ocean, so that ecological responses could be observed. Kiko and other atmospheric cyclones, along with mesoscale ocean eddies, introduce spatial and temporal variability in this relatively low-variability region. For the recent $40 \mathrm{yr}$ of reliable records (19712010), 15.2 tropical storms (range 7-25), 8.5 hurricanes (range 3-16), and 3.9 (range 0-9) major hurricanes per year have formed in the eastern Pacific region (NWS/Climate Prediction Center, www.cpc. ncep.noaa.gov/products/Epac_hurr/background_in formation.html). The temporal and spatial dynamics of these atmospheric storms and oceanic eddies comprise a disturbance regime (Turner 2010, Peters et al. 2011). This pattern may be fundamental to the functioning of the ecosystem by enhancing resources for both resident and seasonally migrating top predators. Ecosystem modeling, and further observations of feeding and migration, and are needed to explore this question.

Acknowledgements. We thank the scientists and crew of the NOAA ship 'McArthur II' for ensuring the collection of quality data, Eric Archer and Annette Henry for planning and managing the STARLITE survey, Corey Sheredy for measuring zooplankton volumes and editing seabird sighting data, and Al Jackson for editing cetacean sighting data. Daniel Palacios and Sam McClatchie read an early version of the paper and provided helpful comments. Two anonymous reviewers provided comments that helped to improve the paper.

\section{LITERATURE CITED}

Babin SM, Carton JA, Dickey TD, Wiggert JD (2004) Satellite evidence of hurricane-induced phytoplankton blooms in an oceanic desert. J Geophys Res 109:C03043, doi: 10.1029/2003JC001938 
Bailey H, Mate BR, Palacios DM, Irvine L, Bograd SJ, Costa DP (2009) Behavioural estimation of blue whale movements in the Northeast Pacific from state-space model analysis of satellite tracks. Endang Species Res 10: 93-106

Ballance LT (2007) Understanding seabirds at sea: why and how? Mar Ornithol 35:127-135

Barange M, Allen I, Allison E, Badjeck MC and others (2011) Predicting the impacts and socio-economic consequences of climate change on global marine ecosystems and fisheries: the QUEST_Fish framework. In: Ommer RE, Perry RI, Cochrane K, Cury P (eds) World fisheries: a socialecological analysis. Wiley-Blackwell, Chichester, p 31-59

Baum JK, Worm B (2009) Cascading top-down effects of changing oceanic predator abundances. J Anim Ecol 78: 699-714

Beisner BE, Haydon DT, Cuddington K (2003) Alternative stable states in ecology. Front Ecol Environ 1:376-382

Blomqvist S, Peterz M (1984) Cyclones and pelagic seabird movements. Mar Ecol Prog Ser 20:85-92

Bugoni L, Sander M, Costa ES (2007) Effects of the first southern Atlantic hurricane on Atlantic petrels (Pterodroma incerta). Wilson J Ornithol 119:725-729

Cury P, Shannon L, Shin YJ (2003) The functioning of marine ecosystems. In Sinclair M, Valdimarsson G (eds) Responsible fisheries in the marine ecosystem. FAO, Rome, p 103-124

> Fauchald P, Skov H, Skern-Mauritzen M, Hausner VH, Johns D, Tveraa T (2011) Scale-dependent response diversity of seabirds to prey in the North Sea. Ecology 92: 228-239

> Fearnbach H, Durban J, Parsons K, Claridge D (2012) Seasonality of calving and predation risk in bottlenose dolphins on Little Bahama Bank. Mar Mamm Sci 28: 402-411

Fiedler PC (2010) Comparison of objective descriptions of the thermocline. Limnol Oceanogr Methods 8:313-325

> Fiedler PC, Talley LD (2006) Hydrography of the eastern tropical Pacific: a review. Prog Oceanogr 69:143-180

> Frank KT, Petrie B, Shackell NL (2007) The ups and downs of trophic control in continental shelf ecosystems. Trends Ecol Evol 22:236-242

> Gerrodette T, Forcada J (2005) Non-recovery of two spotted and spinner dolphin populations in the eastern tropical Pacific Ocean. Mar Ecol Prog Ser 291:1-21

> Hanshaw MN, Lozier MS, Palter JB (2008) Integrated impact of tropical cyclones on sea surface chlorophyll in the North Atlantic. Geophys Res Lett 35:L01601, doi:10.1029/ 2007 GL031862

> Hass T, Hyman J, Semmens BX (2012) Climate change, heightened hurricane activity, and extinction risk for an endangered tropical seabird, the black-capped petrel Pterodroma hasitata. Mar Ecol Prog Ser 454:251-261

Holling CS (2001) Understanding the complexity of economic, ecological, and social systems. Ecosystems 4:390-405

Hunter MD, Price PW (1992) Playing chutes and ladders: heterogeneity and the relative roles of bottom-up and top-down forces in natural communities. Ecology 73: 724-732

> Hutchinson GE (1941) Ecological aspects of succession in natural populations. Am Nat 75:406-418

Knutson TR, McBride JL, Chan J, Emanue K and others (2010) Tropical cyclones and climate change. Nat Geosci 3:157-163

Kramer D, Kalin MJ, Stevens EG, Thrailkill JR, Zweifel JR
(1972) Collecting and processing data on fish eggs and larvae in the California Current region. NOAA Tech Rep NMFS Circular 370

Levin PS, Fogarty MJ, Murawski SA, Fluharty D (2009) Integrated ecosystem assessments: developing the scientific basis for ecosystem-based management of the ocean. PLoS ONE 7:e1000014

Liang JH, McWilliams JC, Gruber N (2009) High-frequency response of the ocean to mountain gap winds in the northeastern tropical Pacific. J Geophys Res 114:C12005, doi:10.1029/2009JC005370

> Lin II (2012) Typhoon-induced phytoplankton blooms and primary productivity increase in the western North Pacific subtropical ocean. J Geophys Res 117:C03039, doi:10.1029/2011JC007626

Lindeman RL (1942) The trophic-dynamic aspect of ecology. Ecology 23:399-417

Liu X, Wang M, Shi W (2009) A study of a Hurricane Katrina-induced phytoplankton bloom using satellite observations and model simulations. J Geophys Res 114: C03023, doi:10.1029/2008JC004934

Longhurst AR (2007) Ecological geography of the sea, 2nd edn. Academic Press, Burlington, MA

Manikowski S (1971) The influence of meteorological factors on the behaviour of sea birds. Acta Zool Cracov 16: 581-668

> Marsh HE (1989) Mass stranding of dugongs by a tropical cyclone in northern Australia. Mar Mamm Sci 5:78-84

Mignucci-Giannoni AA, Toyos-González GM, Pérez-Padilla J, Rodríguez-López MA, Overing J (2000) Mass stranding of pygmy killer whales (Feresa attenuata) in the British Virgin Islands. J Mar Biol Assoc UK 80:759-760

Miller LJ, Mackey AD, Hoffland T, Solangi M, Kuczaj SA (2010) Potential effects of a major hurricane on Atlantic bottlenose dolphin (Tursiops truncatus) reproduction in the Mississippi Sound. Mar Mamm Sci 26:707-715

$>$ Overland JE, Alheit J, Bakun A, Hurrell JW, Mackas DL, Miller AJ (2010) Climate controls on marine ecosystems and fish populations. J Mar Syst 79:305-315

> Paine RT, Levin SA (1981) Intertidal landscapes: disturbance and the dynamics of pattern. Ecol Monogr 51:145-178

> Peters DPC, Lugo AE, Chapin FS, Pickett STA and others (2011) Cross-system comparisons elucidate disturbance complexities and generalities. Ecosphere 2:art81, doi: 10.1890/ES11-00115.1

Philbrick VA, Fiedler PC, Ballance LT, Demer DA (2003) Report of ecosystem studies conducted during the 2001 Oregon, California, and Washington (ORCAWALE) marine mammal survey on the research vessels David Starr Jordan and McArthur. NOAA Tech Memo NOAA-TMNMFS-SWFSC-349

Platt T, Denman KL (1975) Spectral analysis in ecology. Annu Rev Ecol Syst 6:189-210

Price JF, Sanford TB, Forristall GZ (1994) Forced stage response to a moving hurricane. J Physiol Oceanogr 24: 233-260

Reilly SB, Thayer VG (1990) Blue whale (Balaenoptera musculus) distribution in the eastern tropical Pacific. Mar Mamm Sci 6:265-277

Schwarz LK, Gerrodette T, Archer FL (2010) Comparison of closing and passing mode from a line-transect survey of delphinids in the eastern Tropical Pacific Ocean. J Cetacean Res Manag 11:253-265

Shi W, Wang M (2011) Satellite observations of asymmetrical physical and biological responses to Hurricane Earl. 
Geophys Res Lett 38:L04607, doi:10.1029/2010GL046574

Sun L, Yang YJ, Xian T, Wang Y, Fu YF (2012) Ocean responses to typhoon Namtheun explored with Argo floats and multiplatform satellites. Atmos-ocean 50(Suppl 1): $15-26$

Tuck LM (1968) Laughing gulls (Larus atricilla) and black skimmers (Rynchops nigra) brought to Newfoundland by hurricane. Bird Banding 39:200-208

Turner MG (2010) Disturbance and landscape dynamics in a changing world. Ecology 91:2833-2849

Van Noord JE, Lewallen EA, Pitman RL (in press) Flyingfish feeding ecology in the eastern Pacific: prey partitioning within a speciose epipelagic community. J Fish Biol

Vance TC, Doel RE (2010) Graphical methods and Cold War scientific practice: The Stommel Diagram's intriguing journey from the physical to the biological environmental sciences. Hist Stud Nat Sci 40:1-47

Wang M, Liu X, Shi W (2011) Hurricane-induced phytoplankton blooms: satellite observations and model nu-

Editorial responsibility: Antonio Bode,

A Coruña, Spain merical simulations. In: Lupo A (ed) Recent hurricane research: climate, dynamics, and societal impacts. http://www.intechopen.com/books/recent-hurricaneresearch-climate-dynamics-and-societalimpacts/hurricaneinduced-phytoplankton-blooms-satellite-observationsand-numerical-model-simulations

White PS, Pickett STA (1985) Natural disturbance and patch dynamics: an introduction. In: Pickett STA, White PS (eds) The ecology of natural disturbance and patch dynamics. Academic Press, New York, NY, p 3-13

White SC, Robertson WB, Ricklefs RE (1976) The effect of Hurricane Agnes on growth and survival of tern chicks in Florida. Bird Banding 47:54-71

Wiley JW, Wunderle JM (1993) The effects of hurricanes on birds, with special reference to Caribbean islands. Bird Conserv Int 3:319-349

> Willett CS, Leben RR, Lavín MF (2006) Eddies and tropical instability waves in the eastern tropical Pacific: a review. Prog Oceanogr 69:218-238

Submitted: February 4, 2013; Accepted: April 16, 2013 Proofs received from author(s): May 29, 2013 